\title{
RELIGIOSITY IN CRIMINAL LAW: ISLAMIC PERSPECTIVE
}

\author{
Abdurrahman Raden Aji Haqqi \\ Faculty of Shariah and Law, Universiti Islam Sultan Sharif Ali (UNISSA) \\ Brunei Darussalam \\ abdurrahman.haqqi@unissa.edu.bn
}

\begin{abstract}
The fundamental premises of Islamic law are that Allah has revealed His will for human-kind in the Holy Quran and the inspired example of the Prophet Muhammad (Peace be Upon Him), and that society's law must conform to Allah's revealed will. The scope of Islamic law is broader than the common law or civil law. In addition to core legal doctrines covering the family, wrongs, procedure, and commercial transactions, Islamic law also includes detailed rules regulating religious ritual and social etiquette. In Islam, religiosity is not asceticism in monasteries nor is it chattering from the pulpits. Instead, it is behaving in a manner that is requested from the Creator under all circumstances, places and times, in belief, statement and actions. Historically, law and religion have never been completely separated. They have never been so independent as to achieve complete autonomy from each other. Religion has essentially been embodied in legal systems, even in those that have aspired to privatize religion. Based on this fact, this paper discusses such fact i.e religiosity on specific theme of Islamic law that is criminal law which means the body of law dealing with wrongs that are punishable in Islamic law with the object of deterrence.
\end{abstract}

Keywords: Islamic Law; Religiosity; The Will of God; Islamic Criminal Law

\section{Introduction}

Modern law and religion are essential sociopolitical phenomena that have in common some veiled elements. Both aspire to constitute, or at least to frame, human consciousness and behaviour in all spheres of private and public life. Accordingly, modern law and religion are complementary, contradictory and simultaneous sources of rule-making, adjudication and execution. Both embed obedience and obligations, leadership, institutions and legal ideology as foundations of their maintenance and prevalence, based on a strict structure of commands. Modern law and religion are engendered through written and oral intergenerational - sometimes transnational - texts that are enforceable through authorities, and are subjected to authoritative, corresponding and alternative hermeneutics. ${ }^{1}$

In the religious sense, law can be thought of as the ordering principle of reality; knowledge as revealed by God defining and governing all human affairs. Law, in the religious sense, also includes codes of ethics and morality which are upheld and required by God. Examples include customary Hindu law, Islamic law, and the divine law of the Mosaic code or Torah. ${ }^{2}$

\footnotetext{
${ }^{1}$ Barzilai, Gad,Law and Religion, England: Ashgate Publishing Limited, 2007, p. xi

${ }^{2}$ See: Wikipedia, 'Religious law'.
} 
The first and foremost source of Islamic law is the Holy Qur'an. It was revealed gradually over a period of some two decades and its application was done by rejecting, modifying, condoning or accepting the prevalent socio-cultural and economic norms as deemed compatible with the new set of social norms enshrined in the Holy Qur'an. Therefore, in order to gain a proper understanding of the laws, this must be understood in the context of the revelation of each of its verse.

The ultimate objective of every Islamic legal injunction is to secure the welfare of humanity in this world and the next by establishing a righteous society. This is a society that worships God and flourishes on the Earth, one that wields the forces of nature to build a civilization wherein every human being can live in a climate of peace, justice and security. This is a civilization that allows a person to fulfill his every spiritual, intellectual, and material need and cultivate every aspect of his being. This supreme objective is articulated by the Quran in many places. ${ }^{3}$ God says: "We have sent our Messengers with clear signs and have sent down with them the book and the criterion so that man can establish justice. And we sent down iron of great strength and many benefits for man..." (Quran Surah al-Hadid, 57:25)

According to Rudolf Peter in his book titled Crime and Punishment in Islamic Law Theory and Practice from the Sixteenth to the Twenty-First Century criminal law means: "the body of law that regulates the power of the state to inflict punishment, i.e. suffering, on persons in order to enforce compliance with certain rules." Such rules typically protect public interests and values that society regards as crucial, even if the immediate interest that is protected is a private one. ${ }^{4}$

However, "All the theories of criminality, propounded by the Western Criminologists, originate from the distorted vision of human nature, based on 'Trial and Error Method'. Islamic concept of crime, like the concept of law, is permanent, unchanging and unanimous among all the scholars and schools of law: "Crime is an unlawful act for which punishment has been prescribed by the Shariah by way of fixation or discretion."

The concept of Islamic criminal law is different from the concept of criminal law in the man-made law. The man-made law defines crime as an offence against the public where it relates to the rights of the society only. On the contrary, in Islamic criminal law, it also covers the rights of individuals as well as the rights of society. Hence, "Islamic criminal law divides

\footnotetext{
${ }^{3}$ Dr. Abdurrahman al-Muala. (2006). "Crimes and Punishment in Islam”, www.islamtoday.com, last modified 16 Oct 2011.

${ }^{4}$ Rudolf Peter. (2005). Crime and Punishment in Islamic Law Theory and Practice from the Sixteenth to the TwentyFirst Century. UK: Cambridge University Press, p, 1.

${ }^{5}$ See: Dr Muhammad Tahir-ul-Islam, "Islamic Penal System and Philosophy"
} 
crimes into categories that are distinct from those employed in most common law and civil law countries." 6

The cultural hemisphere of the Muslim world has been on the spotlight of international interest ever since the events of 9-11. One of the most controversially debated issues within this context is the Islamic criminal law as such, which is "the epitome of Islamic thought, the most typical manifestation of the Islamic way of life, the core and kernel of Islam itself', as Joseph Schacht, an eminent scholar of Islamic jurisprudence has once described it. ${ }^{7}$ However, there is a general debate about the Sharia, as it is commonly called, without much understanding of the basic principles of this law which often leads to misconceptions and prejudice. The pictures usually evoked - regarding the Muslim legal practise - are preoccupied with extraordinary cruelty and hardship imposed upon offenders to the law. Cutting off hands as a common practice for thieves or stoning adulteresses are popular images of a very one-sided debate. ${ }^{8}$

International crime statistics indicate that in Islamic countries crime rates are lower than in other countries. This feature of Islamic countries is most often explained by two factors: a) the relatively low level of development, which has a positive effect on crime rates, and b) the strictness of Islamic penal law. ${ }^{9}$

This paper attempts to clarify that criminal law in Islam is considered as divinely law and there is religiosity in implementing and practicing it. Hence, the believers are obliged to implement and practice it as they have been implemented and practiced any other religious duties and activities.

\section{Discussion}

\subsection{Religiosity Means}

Religiosity ${ }^{10}$ can mean "piety" or "the state of being religious"... To be religiose is to be “excessively or sentimentally religious" or to practice one's religion in a meddlesome way. Thus,

\footnotetext{
${ }^{6}$ Susan C. Hascall, "Restorative Justice in Islam: Should Qisas Be Considered a Form of Restorative Justice?” in Berkelly J of Meadle Eastern and Islamic Law, 2011, vol. 4:1, p. 37.

7 Schacht, Joseph. 1950. Origins of Muhammadan Jurisprudence. Oxford, $124 \mathrm{ff}$.

${ }^{8}$ Mohamed al-Awabdeh. 2005. "History and Prospect of Islamic Criminal Law with Respect to the Human Rights", Ph D Dissertation submitted to Faculty of Law, Humboldt-Universität, Berlin in 2005, p. 6.

9 Seyed Hossein Serajzadeh, "Islam and Crime: the Moral Community of Muslims", Journal of Arabic and Islamic Studies 4 (2001-2002), p. 111.

${ }^{10}$ Religiosity (rIlidzinsiti) - uncountable noun: If you refer to a person's religiosity, you are referring to the fact that they are religious in a way which seemsexaggerated and insincere. (COBUILD Advanced English Dictionary. Copyright (C) HarperCollins Publishers); Religiosity in American English (rı,lıdzi' asəti; rilij, eäs 'ətē) - noun: the quality of being religious, esp. of being excessively, ostentatiously, or mawkishly religious. (Webster's New World College Dictionary, 4th Edition. Copyright (C) 2010 by Houghton Mifflin Harcourt); Derived forms:
} 
religiosity is characterized by excessive involvement in religious activities. Religiosity usually entails extreme zeal outside of and beyond the norms of one's faith. It is more than affection for religion; it is affectation in religion. Religiosity usually reflects one's individual beliefs more than those of the religious organization itself. Another term for religiosity, though less common, is religiousness, "the state of being superficially religious.", 11

The concept of religiosity in Islam is misunderstood by many people including some Muslims. Religiosity is commonly taken to mean performing ritualistic acts such as prayers, fasting, charity, pilgrimage etc. This limited understanding of religiosity is only one part of the meaning of worship in Islam. That is why the traditional definition of religiosity in Islam is a comprehensive definition that includes almost everything in any individual's activities. The definition goes something like this: "religiosity is an inclusive term for all that God loves of external and internal sayings and actions of a person." In other words, religiosity is everything one says or does for the pleasure of Allah. This, of course, includes rituals as well as beliefs, social activities, and personal contributions to the welfare of one's fellow human-beings. Islam looks at the individual as a whole. He is required to submit himself completely to Allah, as the Quran instructed the Prophet Muhammad to do: "Say (O Muhammad) my prayer, my sacrifice, my life and my death belong to Allah; He has no partner and I am ordered to be among those who submit, i.e.; Muslims." (Quran, Surah Al-An'am: 162-163)

Religiosity in Islam is worship per se. Worship is 'Ibadah in Islamic term. The Arabic word 'ibadah (عبادة), usually translated "worship", is connected with related words literally meaning "slavery", and has connotations of obedience, submission, and humility. In terms of Islam, 'ibadah is the ultimate obedience, the ultimate submission, and the ultimate humility to Allah along with the ultimate love for Him. Muslims believe that 'ibadah is the reason for the existence of all humanity. That is, Muslims believe that all people exist only to worship Allah. 'Ibadah consequently means following Islamic beliefs and practices - its commands, prohibitions, the halal, and the haram. For Muslims, 'ibadah is also something that comes from the heart, or sincerity, as a result of belief in Islam. Therefore, 'ibadah is something

religiose (re'ligi, ose) (rı, lıdzi, ous; rilij, $\overline{\text { ēôs }}$ ) -adjective; Word origin of 'religiosity' ME religiosite $<\mathrm{LL}(\mathrm{Ec})$ religiositas; Example sentences containing 'religiosity': "Perhaps a nation that wantspublic religiosity is better than one that has abandoned it." Christianity Today (2000). https://www.collinsdictionary.com/dictionary/english/religiosity.

${ }^{11}$ https://www.gotquestions.org/religiosity.html 
that cannot be forced upon another person. Allah The Most High says to the effect: "I did not create

\subsection{Islamic Criminal law}

A discussion on Islamic criminal law and its punishments system is important for a number of reasons: Firstly, similar to the conventional system, a crime is a public wrong and thereby brings laws relating thereto to the realm of the public. Islamic criminal law is therefore central to the entire Islamic legal system; Secondly, religio-political parties in a number of Muslim countries have increasingly been advocating for the application of the Islamic criminal justice system within their respective jurisdictions. Countries such as Saudi Arabia, Iran, Sudan, Pakistan and Nigeria have demonstrated the application of the law in varying degrees; Thirdly, the use of the law has had wider implications. This is particularly so when one considers the compatibility of this law with international human rights treaties, to which the Muslim countries are party. These are but a few reasons as to why the Islamic criminal justice system has become an important, and arguably, the most discussed branch of Islamic law. ${ }^{12}$

According to L.B. Curzon, crime is any act or omission resulting from human conduct which is considered in itself or in its outcome to be harmful and which the State wishes to prevent, which renders the person responsible liable to some kind of punishment as the result of proceedings which are usually initiated on behalf of the State and which are designed to ascertain the nature, extent and legal consequence of that person's responsibility. In Board of Trade v. Owen, the House of Lords adopted as a definition that given in Halsbury's Laws of England: a crime is an unlawful act or default which is an offence against the public and renders the person guilty of the act liable to legal punishment. ${ }^{13}$

Hence in general criminal law (penal law) is the body of laws which regulate governmental sanctions (such as imprisonment and/or fines) as retaliation for crimes against the social order. ${ }^{14}$ The Western liberal constitutional myth of the separation of religion from the state is utterly problematic since religion is irreducibly significant in formation of modern states, laws and legal ideologies. Thus, surveys in Europe, for example, demonstrate to what degree religion is prominent in both liberal and post-communist political regimes. In relation to religious practices of praying in church, the figures are illuminating: 88 per cent in Ireland, 85 per cent in Poland,

\footnotetext{
${ }^{12}$ Lawan, Mamman. et. al. (2011), An Introduction to Islamic Criminal Justice: A Teaching and Learning Manual. UK: UK Centre for Legal Educators, p. 3-4.

${ }^{13}$ See: "The Concept of Crimes in Islam", http://termizi-mylife.blogspot.com/2008/01/concept-of-crime-inislam.html

${ }^{14}$ Wikipedia, 'Religious Law'.
} 
69 per cent in Northern Ireland, 51 per cent in Italy, 43 per cent in Switzerland, 41 per cent in Portugal, 39 per cent in Spain, 34 per cent in Hungary, 34 per cent in West Germany, 30 per cent in the Netherlands, 24 per cent in the UK, 20 per cent in (East) Germany and 17 per cent in France attended church 'at least monthly'. Obviously, fluctuations in levels of secularization and religiosity are to be expected. Yet the significance of religion as a central political and legal phenomenon in modernity is far from being marginal. ${ }^{15}$

Hence, the goal of this project [Basic Values of Western and Islamic Criminal Law] is the identification, comparative analysis, and description of the fundamental axioms, value measures, and techniques that differentiate western and Islamic criminal law. Such fundamental, underlying principles are, for example, the concept of the state governed by the rule of law, which in Islamic criminal law - in contrast to secular, western criminal law - is characterized as a theocracy; the concept of human rights, which in Islamic criminal law is not influenced by humanism, as it is in the west, but by religious rules; and the purpose of criminal law, which in Islamic criminal law is seen not only in the protection of society and of individual liberty but also in the protection of religious values. ${ }^{16}$

The word jurm ( جرم ), jarimah (جريمة ) and jināyah (جناية ) are used for crime and offence in Islamic criminal law. The root word jurm literally means to cut off. It is said " جرمد جه ج (He cut it off), جرم صوف الثناة (He shore or sheared or cut off the wool of the sheep). The Holy Qur'ān says: "And let not the hatred of others to you make you swerve to wrong and depart from justice." (Al-Quran, Surah al-Maidah: 8)

Thus the word jurm means a sin, a crime, a fault, an offence, or an act of disobedience, a transgression, ${ }^{17}$ whether intentional or committed through inadvertence. It is for this reason that this word has been used for unfair earning and unfair action. It has been used in verses 5:8, 11:89, 77:46 and 83: 29 of the Holy Qur'ān in the same sense. It is derived from these verses that all that is against justice and right path is called jurm and the person who does unfair and unjust action is called mujrim (مجرم). All the orders of Sharīà are fair being the orders of Allah and His Prophet(PBUH) and thus their disobedience amounts to jurm. Therefore the word jurm

\footnotetext{
15 Barzilai, "Law and Religion, p. xii-xiii.

${ }^{16}$ Mohammad Sadr Touhid-Khaneh. 2014. "Basic Values of Western and Islamic Criminal Law. Ph. D Thesis at University of Freiburg, Germany.

17 See: Ma'an Z. Madina. 1973. Arabic - English Dictionary of the Modern Literary Language. New York: Pocket Books.
} 
signifies to do what has been prohibited in Sharīah or not to do what has been ordered by Sharī`ah to be done and for which punishment of hadd or ta $z \bar{\imath} \mathbf{r}$ has been prescribed. ${ }^{18}$

According to the majority of the jurists, Jināyah signifies all kinds of prohibited and injurious actions whether they relate to human body or property or other violations. However, according to some jurists, it indicates prohibited act, which is committed upon a person like murder, causing hurt etc., while according to others it signifies the offences liable to hudūd and qisās. But, generally the jurists do not differentiate between jurm and jināyah and consider them synonym. $^{19}$

However, as the jurists deal with the matters of proving the crimes in a court and execution of their punishments, they have defined jurm and jināyah in that context. According to Anwarullah, the word crime is an act or omission in which any provision of divine law is violated and is declared punishable. ${ }^{20}$

Hashim Mehat wrote that, crime or jināyah in Islam means committing sins either (i) committing what is forbidden (by Allah), or (ii) omitting what is commanded by Allah. In other words committing what is harām (unlawful) and omitting what is wājib are more or less similar to the concept of 'criminal act' and 'criminal omission' provided in section 33 of Malaysian Penal Code. Based on this, al-Māwardī defined 'hudūd' as deterrent punishments which God (Allah) established to prevent man from commission of what He forbade and from neglecting what He commanded. Al-Māwardī proceeded further to define 'jināyah' (crime) in Islam as 'legal prohibitions against which Allah deters through hadd or $t a{ }^{`} z \bar{\imath} r .{ }^{21}$ The legal prohibitions (al-mahzūrāt al-shar ‘iyyah) here mean commission of harām and omission of wājib or fard. ${ }^{22}$

Islamic criminal law is based on the principle of individual responsibility. Persons are punished for their own acts. Collective punishment is not allowed, although there are exceptional cases of collective liability, such as in the Hanafite qasama doctrine, where the inhabitants of a house or village can be held liable for the financial consequences of a homicide with an unknown perpetrator, committed in the house or village. Under certain circumstances a person who has committed an offence is not responsible for the consequences. Some of these circumstances are connected with the absence of mens rea, the 'guilty mind' or the blameworthiness of the

\footnotetext{
${ }^{18}$ See: Abdurrahman Raden Aji Haqqi, "Muzakkirat fi Jinayat 1", Kuwait University, 1988; "The Concept of Crimes in Islam".

${ }^{19}$ Ibid.

${ }^{20}$ Ibid.

${ }^{21}$ Al-Mawardi, Abu Hasan Ali ibn Muhammad. N.d. al-Ahkam al-Sultaniyyah. Dar al-Kutub al-'Ilmiyyah, p.273.

${ }^{22}$ See: Abdurrahman Raden Aji Haqqi, "Muzakkirat fi Jinayat 1", Kuwait University, 1987; “The Concept of Crimes in Islam".
} 
defendant, for instance because the offence was committed by a minor or an insane person. In such cases the offence cannot be imputed to the offender. Other circumstances cause the offence to lose its unlawful character (actus reus): an act which contains all the elements of a crime and can be imputed to the person who has committed it must sometimes be regarded as lawful because of a justifying circumstance, such as for instance self-defence. ${ }^{23}$

In Islamic criminal law, punishments form only a small component of Islamic law, and are fixed only for a very limited number of offenses. The constant association of Islamic law with stoning for adultery and amputation for thefts in the modern media is a deliberate effort to misrepresent the true nature of Islamic law. The Shari'ah is not a vindictive, vengeful penal system focused on punishment. On the contrary, it is a comprehensive ethical code that emphasizes the universal values of peace, compassion and forgiveness and seeks to build an ideal society based on its noble ideals. The fact that out of the vast array of crimes known to man, only six- and according to some scholars, four- have been identified by the Shari'ah for fixed punishments is testimony to this fact. The rest of the crimes, which include even murder, are open to arbitration and even pardon by the victims. Where else, can the family of a murdered individual grant clemency and forgive the killer? In contrast, some Western penal systems in modern nations carry a mandatory death penalty for murder. ${ }^{24}$

Islamic criminal law has certain mechanisms in place to actually prevent the implementation of legal punishments. How many people are aware that the Messenger of Allah stated the following?:"Ward off the hudood punishments from the Muslims as much as you can. If there is any possible way for the accused, let him go. For a judge ${ }^{25}$ to err in pardon is better than his erring in punishment.",26

But in addition to those very general aims, Islam also sees punishment as a necessary requisite of divine justice and the Sharia "as the most prominent distillation of Islamic morals and law." 27 This has to do with the strong connection of religious and state affairs in the Muslim world. Any judicial proceeding operates on the ground of divine affirmation; justice is pronounced in the name of God. It is believed that all penalties following the accusation and trial

\footnotetext{
${ }^{23}$ Peter, Crimes and Punishment, p. 20.

${ }^{24}$ Dr. Abu Zayd. 2005. "The Face of Mercy”. p. 3. https://obeyd.files.wordpress.com/2007/10/mercy-in-islamiclaw.pdf

${ }^{25}$ The term used is imam, or leader of the state, but it has been interpreted by jurists to include judges as the separation of political and legal authority occurred early in Islamic history.

${ }^{26}$ Narrated by Al-Tirmidhi \#1344 with a weak chain. However, all jurists have accepted this hadith and used it in their works on the basis of other chains that strengthen it. Categorized as authentic (sahih) by al-Hakim

${ }^{27}$ Forte, David F. 1999. Studies in Islamic Law. Oxford, $236 \mathrm{ff}$.
} 
of an offender to the law are measured with a divine balance of justice. Punishments are, therefore, harsh where necessary and lenient where appropriate. No matter how harsh the sentence may be, it is viewed as ultimately merciful. ${ }^{28}$

\subsection{Sources of Islamic Criminal Law}

Since the Islamic legal injunctions are aimed at achieving human welfare, they can all be referred back to universal principles which are necessary for human welfare to be secured. These universal principles are: the preservation of life; the preservation of religion; the preservation of reason; the preservation of lineage; the preservation of property.

The Islamic penal system is aimed at preserving these five universal necessities. To preserve life, it prescribes the law of retribution. To preserve religion, it prescribes the punishment for apostasy. To preserve reason, it prescribes the punishment for drinking. To preserve lineage, it prescribes the punishment for fornication. To preserve wealth, it prescribes the punishment for theft. To protect all of them, it prescribes the punishment for highway robbery. ${ }^{29}$

Islamic criminal law is rooted in the divinely code that finds expressing in the Qur'an and Sunnah. The sources of Islamic criminal law are referred to four principal proofs, namely the Qur'an, Sunnah, consensus ('Ijma') and analogy (Qiyas). Sources in this sense are synonymous with usul (sing. asl), hence the four sources of Islamic criminal law are known both as adillah and usul. There are a number of ayat in the Qur'an which identify the sources of Islamic law including criminal one and the order of priority between them. But one passage in which all the principal sources are indicated occurs in ayat which says: 'O you believers! Obey God and obey the Messenger and those of you who are in charge of affairs. If you have a dispute concerning any matter, refer it to God and to the Messenger.' (al-Quran, Surah al-Nisa, 4: 58-59) 'Obey God' in this ayah refers to the Qur'an, and 'Obey the Messenger' refers to the Sunnah. Obedience to 'those who are in charge of affairs' is held to be a reference to ijma', and the last portion of the ayah which requires the referral of disputes to God and to the Messenger authorises qiyas. For qiyas is essentially an extension of the injunctions of the Qur'an and Sunnah. The rationale or the effective cause of qiyas may be clearly indicated in these sources or it may be identified by way

\footnotetext{
${ }^{28}$ Al-Awabdeh, "Historical...", p. 22-23.

${ }^{29}$ Al-Muala. "Crimes and Punishment in Islam".
} 
of inference (istinbat). In either case, qiyas essentially consists of the discovery of a hukm which is already indicated in the divine sources. ${ }^{30}$

To conclude crime as defined in the Shariah consists is legal prohibitions imposed by Allah, whose infringement entails punishment prescribed by him. "Crime as defined in the Shariah is identical with Crime as defined in modern law". ${ }^{31}$ In Islamic criminal laws everything prohibited by God and his prophet is a Crime. Unlike in Western law where only that which has a specified punishment is a Crime, in Islamic law every crime is punishable but not every punishment is specified. The role of the State is to ensure that, in a person's public conduct, he does not commit a crime or any act likely to lead to one. Islamic law does not empower the State to infringe on the right of an individual citizen. It cannot break into a man's room and punish him for adultery. It cannot plant a camera in a hotel room and punish a man based on a recording of a sexual act or drinking spree. But if a man and a woman choose to have sex where four eye witnesses actually see coitus, or if a man chooses to drink his beer in front of his house instead of inside his living room, the act immediately leaves the realm of private conscience to one of public morals and the state punishes this severely. "Crime is an act or conduct whereby a person breaks the law and (ii) infringes upon the rights of others. In the religious parlance it is called "a $\sin " 32.33$

\subsection{Religiosity of Islamic Criminal Law: Isn't It?}

The jurists have discussed three classifications of crime on different aspects, namely: classification according to punishment; classification according to intention; and classification according to violation of rights. ${ }^{34}$

\footnotetext{
${ }^{30}$ See: Mohammad Hashim Kamali. 1991. The Principles of Islamic Jurisprudence. Kuala Lumpur: Pelanduk, p. 19.

${ }^{31}$ Abdusamed, Kader. 1994. Crime and punishment in Islam. Lenasia (South Africa): n.p, $3 \mathrm{ff}$.

${ }^{32}$ Abu Zahra, Mohamed. 1976. Crime in Islam, Cairo: n.p, 26 ff.

${ }^{33}$ Al-Awabdeh, "History...". p. 24-25.

${ }^{34}$ Firstly, the crimes in Islamic criminal law have been classified into three kinds on the basis of the quantum of punishment: Qisās and diyat (crimes of retaliation and blood money); Hudūd (crimes of fixed punishments); and $T a ' z \bar{l} r$ (crimes of discretionary punishment).

Secondly, regarding intention, the crimes have been divided into two kinds: (i) Intentional crimes; and (ii) Unintentional crimes.

Intentional crimes means the crimes wherein the criminal commits crime knowing that he is committing an illegal act and understands the result of his act similar to intentional homicide, intentional hurt, etc. On the other hand, unintentional crimes means the criminal does not intend to commit a crime but he commits the crime by negligence or mistake.

Lastly, the crimes on the basis of violation of rights have been divided into two kinds: crimes against public; and crimes against individuals. The former are preponderantly injurious to the society at large. Such crimes may be committed against individuals as well as against public. And the latter means crimes directly affect the individuals though they are injurious to the public as well.
} 
In the classical text books of fiqh, criminal law is not regarded as a single, unified branch of the law. It is discussed in three separate chapters: (1) Provisions regarding offences against persons, i.e. homicide and wounding, subdivided into (a) those regarding retaliation (qisas) and (b) those regarding financial compensation (diya); (2) Provisions regarding offences mentioned in the Koran and constituting violations of the claims of God (huquq Allah), with mandatory fixed punishments (hadd, plural hudud); these offences are: (a) theft (b) banditry (c) unlawful sexual intercourse (d) the unfounded accusation of unlawful sexual intercourse (slander) (e) drinking alcohol (f) apostasy (according to some schools of jurisprudence); (3) Provisions concerning discretionary punishment of sinful or forbidden behaviour or of acts endangering public order or state security (ta'zlr and siyasa). ${ }^{35}$

Islamic law identified the most serious crimes as those mentioned in the Quran and Sunnah. "These were considered sins against Allah and carried mandatory punishments." 36 These crimes and punishments are: (1) Adultery and fornication: death by stoning or 100 lashes; (2) highway robbery: execution; crucifixion; right hand and left foot cut off; or exile, imprisonment; (3) theft: hand cut off; (4) slander: 80 lashes; (5) drinking wine or any other intoxicant: 40 or 80 lashes; (6) apostasy: killing; (7) rebellion.

Crimes against the person included murder and bodily injury. In these cases, the victim or his male next of kin had the "right of retaliation" where this was possible. This meant, for example, that the male next of kin of a murder victim could execute the murderer after his trial (usually by cutting off his head with a sword). "If someone lost the sight of an eye in an attack, he could retaliate by putting a red-hot needle into the eye of his attacker who had been found guilty by the law". ${ }^{37}$ But a rule of exactitude required that a retaliator must give the same amount of damage he received. If, even by accident, he injured the person too much, he had broken the law and was subject to punishment. The rule of exactitude discouraged retaliation. Usually, the injured person or his kinsman would agree to accept money or something of value ("blood money") instead of retaliating. In a third category of less serious offences such as gambling and bribery, the judge used his discretion in deciding on a penalty. Punishments would often require the criminal to pay reparation to the victim, receive a certain number of lashes, or be locked up. ${ }^{38}$

\footnotetext{
${ }^{35}$ Peter, Crimes and Punishments..., p. 7.

${ }^{36}$ Tahir, Mohamood. 1996. Criminal law in Islam, Delhi, 62ff.

${ }^{37}$ Sayyid, Sabiq. 1953. Fiqh Al Sunnah, Cairo: 330ff.

${ }^{38}$ Al-Awabdeh, "History...", p. 25-26
} 


\section{First: Hudud (Prescribed Punishments)}

Crimes that fall under this category can be defined as legally prohibited acts that God forcibly prevents by way of fixed, predetermined punishments, the execution of which is considered the right of God.

These punishments have certain peculiarities that set them apart from others. Among these are the following:

1) These punishments can neither be increased nor decreased.

2) These punishments cannot be waived by the judge, the political authority, or the victim after their associated crimes have been brought to the attention of the governing body. Before these crimes are brought before the state, it may be possible for the victim to pardon the criminal if the damage done was only personal.

3) These punishments are the 'right of God', meaning that the legal right involved is of a general nature where the greater welfare of society is considered. ${ }^{39}$

The following crimes fall under the jurisdiction of the fixed punishments:

\section{Theft (Sariqah)}

Theft is defined as covertly taking the wealth of another party from its secure location with the intention of taking possession of it. ${ }^{40}$ Source of law: "As to the thief, male or female, cut off their hands as a reward of their own deeds, and as an exemplary punishment from God. For God is Mighty and Wise. But whoever repents and mends his ways after committing this crime shall be pardoned by Allah. Allah is Forgiving and Merciful." (al-Quran, Surah al-Ma'idah, 5:38-9)

The above ayat indicate that the punishment of amputating the hands is prescribed for a thief, both male (Sariq) or female (Sariqah); the punishment, according to the Qur'an, should be جزاء بما كسب نكالا من ' exemplary in nature; the objective of this punishment is stated in the words الله (jaza an bima kasaba nakalan minallah: as a reward of their deeds and as an exemplary punishment); this is merely a punishment in this world. As far as the Hereafter is concerned, a person can only attain salvation if he repents and mends his ways. ${ }^{41} \mathrm{~A}$ hadith reported to say: "By God! If Fatimah the daughter of Muhammad had committed this theft, I would definitely have cut off her hand." 42

\footnotetext{
${ }^{39}$ Al-Muala. "Crimes and Punishment in Islam".

${ }^{40}$ See: Haqqi, “Muzakkirat... ”, 28/3/1988

${ }^{41}$ Javed Ahmad Ghamidi/Shehzad Saleem, "Penal Law in Islam".

${ }^{42}$ Muslim: No. 1688.
} 


\section{Highway Robbery (Hirabah)}

Highway robbery is defined as the activity of an individual or a group of individuals who go out in strength into the public thoroughfare with the intention of preventing passage or with the intention of seizing the property of passers-by or otherwise inflicting upon them bodily harm. ${ }^{43}$ Source of law: "The punishments of those who wage war against Allah and His Prophet and strive to spread disorder in the land are to execute them in an exemplary way or to crucify them or to amputate their hands and feet from opposite sides or to banish them from the land. Such is their disgrace in this world, and in the Hereafter theirs will be an awful doom save those who repent before you overpower them; you should know that Allah is Oft-Forgiving, Ever Merciful." (al-Quran, Surah al-Maidah, 5:33-4)

It is obvious from the style of these verses that the meaning implied by Muharabah (waging war against Allah and His Prophet (sws)) and spreading disorder in the land is when an individual or a group of individuals take the law into their own hands and openly challenge the system of justice which in accordance with the Shari'ah is established in a piece of land. Consequently, under an Islamic government, all those criminals who commit rape, take to prostitution, become notorious for their ill-ways and vulgarity, become a threat to honourable people because of their immoral and dissolute practices, sexually disgrace women because of their wealth and social status, or rise against the government in rebellion, or create a law and order situation for the government by causing destruction, by becoming a source of terror and intimidation for people, by committing mass murder, plunder, decoity or robbery, by indulging in hijacking and terrorism and by committing other similar crimes are criminals of Muharabah, and spreading such disorder in the society should be severely dealt with. ${ }^{44}$

\section{Fornication and Adultery (Zina)}

This is defined as any case where a man has coitus with a woman who is unlawful to him. Any relationship between a man and a woman that is not inclusive of coitus does not fall under this category and does not mandate the prescribed, fixed punishment. ${ }^{45}$ Sources of law: "The man and the woman guilty of fornication, flog each of them with a hundred stripes and let not compassion move you in their case in the enforcement of the law of God, if you truly believe in Allah and the Last Day. And let a party of the believers witness their punishment. The man guilty of fornication may only marry a woman similarly guilty or an idolateress and the woman guilty

\footnotetext{
${ }^{43}$ See: Haqqi, “Muzakkirat...”, 9/4/1988.

${ }^{44}$ Javed Ahmad Ghamidi/Shehzad Saleem, "Penal Law in Islam".

${ }^{45}$ See: Haqqi, “Muzakkirat...", 13/2/1988.
} 
of fornication may only marry such a man or an idolater. The believers are forbidden such marriages." (al-Quran, Surah al-Nur, 24:2-3)

The initial directive of the Qur'an regarding the punishment of fornication is mentioned in Surah Nisa. No definite punishment is mentioned there; it is only said that thantil some directive is revealed about women who as prostitutes habitually commit fornication, they should be confined to their homes, and the common perpetrators of this crime should be tortured until they repent and mend their ways. This torture may range from exhorting and reprimanding, scolding and censuring, humiliating and disgracing the criminal to beating him up for the purpose of reforming him.

And upon those of your women who commit fornication, call in four people among yourselves to testify over them; if they testify [to their ill-ways], confine them to their homes till death overtakes them or God formulates another way for them. And the man and woman among you who commit fornication, punish them. If they repent and mend their ways, leave them alone. For God is Ever-Forgiving and Most Merciful." (al-Quran, Surah al-Nisa, 4:15-6)

This was the punishment of fornication in the Shari'ah before a definite directive was revealed in Surah Nur. Once this was revealed, it repealed the previous directive permanently. The directives mentioned in these verses are: the man or woman who have committed fornication, both shall receive a hundred stripes; the criminal should be given this punishment publicly to humiliate him in front of the people, and to make him a lesson for those present; after this punishment has been carried out, no chaste man or woman should marry men and women who commit fornication; while stating this punishment, adjectives are used to qualify the men and women who commit fornication. ${ }^{46}$

Hadith of the Prophet Sallallahu Alaihi Wasallam: Abu Huraira reported Allah's Apostle as saying: "Allah has decreed for every son of Adam his share of zina, which he will inevitably commit. The zina of the eyes is looking, the zina of the tongue is speaking, one may wish and desire, and the private parts confirm that or deny it." ${ }^{, 47}$

The public lashing and public lethal stoning punishment for zina are also prescribed in Hadiths. 'Ubada b. as-Samit reported: Allah's Messenger as saying: Receive teaching from me, receive teaching from me. Allah has ordained a way for those women. When an unmarried male commits adultery with an unmarried female, they should receive one hundred lashes and

\footnotetext{
${ }^{46}$ See: Javed Ahmad Ghamidi/Shehzad Saleem, "Penal Law in Islam".

${ }^{47}$ Sahih al-Bukhari, 8:77:609; Sahih Muslim, 33:6421
} 
banishment for one year. And in case of married male committing adultery with a married female, they shall receive one hundred lashes and be stoned to death. ${ }^{48}$

Umar ibn al-Khattab said: "Allah's Messenger awarded the punishment of stoning to death to the married adulterer and adulteress and, after him, we also awarded the punishment of stoning, I am afraid that with the lapse of time, the people may forget it and may say: We do not find the punishment of stoning in the Book of Allah, and thus go astray by abandoning this duty prescribed by Allah. Stoning is a duty laid down in Allah's Book for married men and women who commit adultery when proof is established, or if there is pregnancy, or a confession. ${ }^{49}$

\section{False Accusation (Qadhf)}

This is defined as accusing the chaste, innocent person of fornication or adultery. It also includes denying the lineage of a person from his father (which implies that his parents committed fornication of adultery). False accusation includes any claim of fornication or adultery that is not backed up by a proof acceptable to Islamic Law. ${ }^{50}$

Sources of law: "Those who accuse honourable women and bring not four witnesses as an evidence [for their accusation], inflict eighty stripes upon them, and never accept their testimony in future. They indeed are transgressors. But those who repent and mend their ways, Allah is Ever-Forgiving and Most-Merciful. And those who accuse their wives but have no witnesses except themselves shall swear four times by Allah that they are telling the truth and the fifth time that the curse of Allah be on them if they are lying. But this shall avert the punishment from the wife if she swears four times by Allah and says that this person is a liar and the fifth time she says that the curse of Allah be on her if he is telling the truth." (al-Quran, Surah al-Nur, 24:4-9)

This is the directive for Qadhf, ie accusing someone of fornication. Although in these verses only the accusation of women is mentioned, yet in the Arabic language this style which can be termed as 'على سبيل التغليب' ('ala sabil al-taghlib: addressing the dominant element) is adopted because normally in a society only women become targets of such allegations, and the society is also sensitive about them. Consequently, there is no doubt that on the ground of 'similarity of basis' this directive pertains to both men and women and cannot be restricted to women only. ${ }^{51}$

\footnotetext{
${ }^{48}$ Sahih Muslim, 17:4191.

${ }^{49}$ Sahih Muslim, 17:4194

${ }^{50}$ See: Haqqi, “Muzakkirat...", 5/3/1988.

${ }^{51}$ See: Javed Ahmad Ghamidi/Shehzad Saleem, "Penal Law in Islam".
} 


\section{Drinking Intoxication (Shurb al-Khamr)}

One of the most important objectives of Islam is the realization of human welfare and the avoidance of what is harmful. Because of this, it "permits good things and prohibits harmful things." Islam, thus, protects the lives of people as well as their rational faculties, wealth, and reputations. The prohibition of wine and the punishment for drinking it are among the laws that clearly show Islam's concern for these matters, because wine is destructive of all the universal needs, having the potential to destroy life, wealth, intellect, reputation, and religion. ${ }^{52}$

Sources of law: "O you who believe! Verily wine, gambling, idols, and divination are but the abominations of Satan's handiwork, so abandon these things that perchance you will be successful. Satan only wishes to cause enmity and hatred between you through wine and gambling and to prevent you from the remembrance of God and prayer. Will you not then desist?" (al-Quran, al-Maidah, 5:90-91)

\section{Apostasy (Riddah)}

Apostasy is defined as a Muslim making a statement or performing an action that takes him out of the fold of Islam. ${ }^{53}$ Sources of law: "But those who reject Faith after they accepted it, and then go on adding to their defiance of Faith,- never will their repentance be accepted; for they are those who have (of set purpose) gone astray." (al-Quran, Ali Imran, 3: 90) "Make ye no excuses: ye have rejected Faith after ye had accepted it. If We pardon some of you, We will punish others amongst you, for that they are in sin." (al-Quran, al-Taubah, 9: 66)

Allah's Apostle said, "The blood of a Muslim who confesses that none has the right to be worshipped but Allah and that I am His Apostle, cannot be shed except in three cases: In Qisas for murder, a married person who commits illegal sexual intercourse and the one who reverts from Islam (apostate) and leaves the Muslims." ${ }^{54}$

Ali burnt some people and this news reached Ibn 'Abbas, who said, "Had I been in his place I would not have burnt them, as the Prophet said, 'Don't punish (anybody) with Allah's Punishment.' No doubt, I would have killed them, for the Prophet said, 'If somebody (a Muslim) discards his religion, kill him. ${ }^{.55}$

\footnotetext{
${ }^{52}$ See: Haqqi, “Muzakkirat...”, 13/4/1988; al-Ma'ala

${ }^{53}$ Ibid. 1/2/1988

${ }^{54}$ Sahih al-Bukhari, 9:83:17; Sahih Muslim, 16:4152, Sahih Muslim, 16:4154, Sahih Muslim, 20:4490

${ }^{55}$ Sahih al-Bukhari, 4:52:260
} 
The punishment prescribed for it in the Sunnah is execution, and it came as a remedy for a problem that existed at the time of the Prophet, may the mercy and blessings of God be upon him. Thus, the prescribed punishment for apostasy was instituted so that apostasy could not be used as a means of causing doubt in Islam. At the same time, the apostate is given time to repent, so if he has a misconception or is in doubt about something, then his cause of doubt can be removed and the truth clarified to him. He is encouraged to repent for three days.

\section{Second: Retaliation (Qisas)}

1. Intentional Murder

Sources of law: "O you who believe! decreed for you is the Qisas of those among you who are killed such that if the murderer is a free-man, then this free-man should be killed in his place and if he is a slave, then this slave should be killed in his place and if the murderer is a woman, then this woman shall be killed in her place. Then for whom there has been some remission from his brother, [the remission] should be followed according to the Ma'ruf and Diyat should be paid with goodness. This is a concession and a mercy from your Lord. After this, whoever exceeds the limits shall be in a torment afflictive. There is life for you in Qisas $O$ men of insight that you may follow the limits set by Allah." (al-Quran, Surah al-Baqarah, 2:178-9)

\section{Unintentional Murder}

Source of law: "It is unlawful for a believer to kill a believer except if it happens by accident. And he who kills a believer accidentally must free one Muslim slave and pay Diyat to the heirs of the victim except if they forgive him. If the victim is a Muslim belonging to a people at enmity with you, the freeing of a Muslim slave is enough. But if the victim belongs to an ally, Diyat shall also be given to his heirs and a Muslim slave shall also have to be set free. He who does not have a slave, must fast two consecutive months. This is from Allah a way to repent from this sin: He is Wise, All-Knowing." (al-Quran, Surah al-Nisa, 4:92-3)

In Islamic law, according to the Qur'an, the punishment of unintentionally murdering or wounding in some cases is Diyat and Atonement (Kaffarah), and in some cases only Atonement (Kaffarah) except if the wounded person or the heirs of the slain person forgive the criminal. In this case, life for life, wound for wound and limb for limb cannot be demanded from a person. 


\section{Third: $T a$ 'zir (Crimes of Discretionary Punishments)}

Ta zìr literally means disgracing the criminal for his shameful criminal act. In ta $z \bar{\imath} r$, punishment has not been fixed by law, and the $q \bar{a} d i$ is allowed discretion both as to the form in which such punishment is to be inflicted and its measure. This kind of punishment by discretion has been provided in special consideration of the various factors affecting social change in human civilisation and which vary on the basis of variations in the methods of commission or the kind of criminal conduct indictable under the law. Offences punishable by this method are those against human life, property, and public peace and tranquility.

\section{Conclusion}

Based on the facts above and religiosity of Islamic criminal law, the believers are obliged to implement and practice it as they implement and practice all Islamic religious pillars such as salat, Ramadan fasting, pilgrimage in their daily life without any denying and objection. Because salat, Ramadan fasting and pilgrimage are the rules of Allah which must be done, it is also the same regarding the implementation of Islamic criminal law because it is also the rule of Allah which must be done by the believers.

\section{References}

Abdurrahman al-Muala. (2006). "Crimes and Punishment in Islam", www.islamtoday.com, last modified 16 Oct 2011.

Abdusamed, Kader. (1994). Crime and punishment in Islam. Lenasia (South Africa).

Abu al-'Abbas, Ahmad ibn Abdul Halim. (1426H/2005). Majmu' al-Fatawa. $3^{\text {rd }}$ edt. Edt.Anwar al-Baz and Amir al-Jazzar. N.p.: Dar al-Wafa.

Abu Abdullah, Muhammad ibn Ahmad. (1423H/2003). Al-Jami’ Li Ahkam al-Quran. Riyadh: Dar 'Alam al-Kutub,

Abu al-Fida, Ismail ibn Umar ibn Kathir. (1420H/1999). Tafsir al-Quran al- 'Azim. $2^{\text {nd }}$ edt. Edt. Sami Muhammad Salamah. Jeddah: Dar Taybah li al-Tiba'ah wa al-Nashr.

Abu Ya'la al-Musili, Ahmad ibn Ali. (1988). Musnad Abu Ya'la al-Musili. Dar al-Qiblah li alThaqafah al-Islamiyyah

Abu Zahra, Mohamed. (1976). Crime in Islam, Cairo: n.p,. 
Al-Awabdeh, Mohamed. (2005). "History and prospect of Islamic Criminal Law with respect to the Human Rights", Ph D Dissertation submitted to Faculty of Law, Humboldt-Universität, Berlin in 2005.

Al-Baihaqi, Abu Bakar Ahmad ibn al-Husain. (1994). al-Sunan al-Kubra. Beirut: Dar al-Kutub al' 'Ilmiyyah

Al-Bukhari, Muhammad ibn Ismail. (1981). Sahih al-Bukhari. Istanbul:al-Maktabah alIslamiyyah Barzilai, Gad. (2007). Law and Religion. England: Ashgate Publishing Limited.

Al-Mawardi, Abu Hasan Ali ibn Muhammad. (n.d). al-Ahkam al-Sultaniyyah. Dar al-Kutub al'Ilmiyyah.

Al-Mubarakfuri, Abdul Rahman ibn Abdul Rahim.Tuhfah al-'Ahwadhi bisharh Jami' alTirmidhi. Beirut: Dar al-Kutub al'Ilmiyyah

Al-Tabrani, Sulaiman ibn Ahmad. (n.d).Al-Mu'jam al-Kabir. Cairo: Maktabah Ibn Taimiyyah.

Forte, David F. (1999). Studies in Islamic Law. Oxford.

Hascall, Susan C. (2011). "Restorative Justice in Islam: Should Qisas Be Considered a Form of Restorative Justice?" in Berkelly J of Meadle Eastern and Islamic Law, 2011, vol. 4:1

Haqqi, Abdurrahman Raden Aji. (1988). “Muzakkirat fi Jinayat 1”, Kuwait University.

https://www.collinsdictionary.com/dictionary/english/religiosity.

https://www.gotquestions.org/religiosity.html

http://www.islam.com

http://termizi-mylife.blogspot.com/2008/01/concept-of-crime-in-islam.html

https://obeyd.files.wordpress.com/2007/10/mercy-in-islamic-law.pdf

Javed Ahmad Ghamidi/Shehzad Saleem, "Penal Law in Islam".

Kamali, Mohammad Hashim. (1991). The Principles of Islamic Jurisprudence. Kuala Lumpur: Pelanduk.

Lawan, Mamman. et. al. (2011), An Introduction to Islamic Criminal Justice: A Teaching and Learning Manual. UK: UK Centre for Legal Educators.

Ma'an Z. Madina. 1973. Arabic - English Dictionary of the Modern Literary Language. New York: Pocket Books.

Mohammad Sadr Touhid-Khaneh.(2014). "Basic Values of Western and Islamic Criminal Law. $\mathrm{Ph}$. D Thesis at University of Freiburg, Germany

Muhammad Tahir-ul-Islam, "Islamic Penal and Philosophy". 
Muhammad ibn Abu Bakar. (1393H/1973). Madarij al-Salikin bainaManazil Iyyaka Na'budu Wa Iyyaka Nasta'in. $2^{\text {nd }}$ edt. Edt. Muhammad Hamid al-Faqi. Beirut: Dar al-Kitab al'Arabi.

Muslim Hajjaj,(1956).Sahih Muslim. Beirut: Dar al-Turath al-'Arabi, $1^{\text {st }}$ ed.

Peter, Rudolf. (2005). Crime and Punishment in Islamic Law Theory and Practice from the Sixteenth to the Twenty-First Century. UK: Cambridge University Press.

Sayyid, Sabiq. (1953). Fiqh Al Sunnah, Cairo.

Schacht, Joseph. (1950). Origins of Muhammadan Jurisprudence. Oxford.

Seyed Hossein Serajzadeh. (2002). "Islam And Crime: the Moral Community of Muslims", Journal of Arabic and Islamic Studies 4 (2001-2002).

Tahir, Mohamood. 1996. Criminal law in Islam, Delhi: n.p. 